\title{
Does Whitening Happen? Distinguishing between Race and Color Labels in an African-Descended Community in Peru
}

\author{
Tanya Golash-Boza, University of Kansas
}

\begin{abstract}
This article explores how race and color labels are used to describe people in an Afro-Peruvian community. This article is based on analyses of 88 interviews and 18 months of fieldwork in an African-descended community in Peru. The analyses of these data reveal that, if we consider race and color to be conceptually distinct, there is no "mulatto escape hatch," no social or cultural whitening, and no continuum of racial categories in the black Peruvian community under study. This article considers the implications of drawing a conceptual distinction between race and color for research on racial classifications in Latin America. Keywords: blackness, race, skin color, Latin America, whitening.
\end{abstract}

"In the U.S., he who is born black, dies black, whereas in Peru, your social status can change your racial classification."

Alejandro Ortiz, Peruvian anthropologist

"If I was born black, I have to stay black."

Mirella Campoverde, ${ }^{1}$ a young single mother from Ingenio, Peru

Mirella Campoverde and Alejandro Ortiz are both Peruvian, yet they inhabit vastly different worlds. Mirella is a dark-skinned, poor single mother whose future holds little possibility for upward mobility. Dr. Ortiz is a fair-skinned, well-known anthropology professor. Their understandings of the meanings of blackness in Peru seem as distinct as their stations in life. Ortiz is making a general statement about how race works in the United States and in Peru. Mirella is making a particular statement about herself. They are both right. It is very probable that Mirella always will be black, and she always will be referred to as black by others; strangers will assume she knows how to cook and dance; and she will have trouble obtaining employment in positions reserved for whites, such as a receptionist or a bank teller. Ortiz's world is filled with options and possibilities, not only for him, but also, in his view, for Mirella. How do we reconcile these two different maps of the Peruvian racial landscape? This is not only a question about race in Peru. It raises a broader set of questions about the role of class, gender,

1. To protect the privacy of the participants, this name, as well as all of the other names of community members in this article, is a pseudonym.

Research and writing for this article were funded by the University of North Carolina, the University of Illinois at Chicago, the University of Kansas, the National Science Foundation Dissertation Improvement Grant, and the Ford Foundation Peru Dissertation Fellowship. The author thanks Judith Blau, Sandy Darity, Tyrone Forman, Joane Nagel, Izu Ahaghotu, the editor, and the anonymous reviewers for their helpful comments on this article. Previous versions of this article were presented at the Latin American Studies Association congress, the Association of Black Sociologists annual meeting, and the Andean Seminar at the Hall Center for the Humanities at the University of Kansas. Direct correspondence to: Tanya Golash-Boza, 716 Fraser Hall, Sociology, 1415 Jayhawk Blvd., University of Kansas, Lawrence, KS 66045. E-mail: tgb@ku.edu.

Social Problems, Vol. 57, Issue 1, pp. 138-156, ISSN 0037-7791, electronic ISSN 1533-8533. @ 2010 by Society for the Study of Social Problems, Inc. All rights reserved. Please direct all requests for permission to photocopy or reproduce article content through the University of California Press's Rights and Permissions website at www.ucpressjournals.com/reprintinfo/asp. DOI: 10.1525/sp.2010.57.1.138. 
color, geography, and biography in understanding race in Peru, in Latin America, and in North America. These are the questions this article sets out to answer.

The research for this article includes 88 interviews and 18 months of fieldwork in an Afro-Peruvian community between 2002 and 2007. Through the analysis of these data, I explore the disjuncture between Ortiz's and Mirella's views and experiences. For Ortiz (2001), blackness in Peru is contextually dependent and subject to change. For Mirella and other residents of the Afro-Peruvian community analyzed here, blackness is determined by skin color and descent, and does not change over the course of one's life.

Ortiz's indication that social whitening is possible for blacks in Peru resonates with widely accepted conceptualizations of race in Latin America, and with the well-known adage "money whitens." Over the past 50 years, students of race relations have described racial hierarchies in Latin America in three ways: (1) there is an intermediate racial category in Latin America between black and white that serves as a buffer between these two categories; (2) social whitening is a way for a person to become less black; and (3) racial classification in Latin America constitutes a continuum of racial categories. This article explores the extent to which these three claims about race in Latin America can be used to understand the racial hierarchy in the Afro-Peruvian community under study.

These issues are important for scholars to consider as there is an ongoing debate on how racial classifications work in the United States, and the extent to which the United States is becoming more like Latin America (see: Bonilla-Silva 2004; Forman et al. 2004; Golash-Boza and Darity 2008; Sue 2009). These debates require a clear understanding of how race works in Latin America, and this article provides a model for analyzing how race and color classifications work in specific localities.

\section{Conceptual Framework: Race and Color}

Race and color labels are conceptually distinct. Race is an externally imposed social categorization. A racial category is applied to a group of people thought to share physical and cultural traits and a common ancestry. Racial categories are mutually exclusive of one another. The most common markers associated with race are skin color, facial features, and hair texture (Smedley 2007; Wade 1997). Color labels describe gradients of skin color, yet do not refer to mutually exclusive categories of people. In some cases, one word can be used both as a color label and as a racial category. For example, the word "black" in Spanish and English can be used as both a color label and a racial label. An example of the use of black as a color label is when someone says: "I get quite black when I am in the sun all day" in English or "me pongo bien negra cuando estoy en el sol todo el día" in Spanish. In these cases, black is a color, not a racial identifier. Someone could make this declaration without considering herself to be a member of the black race.

I use "category" to refer to races, following Richard Jenkins' (1994, 2000:8) distinction between externally imposed "categories" and internally recognized "groups." In the United States, state actors, social scientists, and others use racial categories to distinguish between people collectively understood to be black, white, Asian, and Native American. These categories have, in turn, produced race-based group identifications-people often understand themselves to belong to one of these groups (Brubaker and Cooper 2000; Nagel 1994). In Peru, racial categories have not been used in official recording efforts such as the Census since 1940. Nevertheless, the long history of racial categorization has influenced how Peruvians talk about themselves and others.

This discussion of race and color requires a further layer of complexity. I draw from Lionel McPherson and Tommie Shelby's (2004:175) analysis of "labels" to do this. Classificatory labels can refer to groups or categories. They also can refer to descriptors that are not groups or categories. I argue that color labels do not refer to categories or groups, whereas racial labels refer to both. Racial categories lead to race-based group identities. Color labels, in contrast, do 
not create group-based identities. This article explores how race and color labels are used, and the extent to which group-based identities form part of the local parlance in an Afro-Peruvian community. This discussion sheds light on the utility of generalizations about race in Latin America for understanding race and color distinctions in the Afro-Peruvian community under study. In the next section, I discuss these generalizations.

\section{Literature Review: Conceptualizations of Race in the Americas}

\section{Mulatto Escape Hatch}

The "mulatto escape hatch" (Degler 1986), also called the "intermediate mulatto stratum" (Safa 1998), refers to the notion that someone can be born black, yet become mulatto through an increase in social status, or intergenerational whitening. This intermediate category emerged from the large free colored population in many Latin American countries during the time of slavery (Safa 1998; Skidmore 1993; Smedley 2007). The creation of the mulatto category, which possessed some benefits over blacks, was a mechanism of social control insofar as the possibility of moving out of the category "black" inhibited alliances among people of African descent (Daniel 2006). Peter Wade (1997) contends that in Latin America, racially mixed children are recognized as socially distinct from their parents. Eduardo Bonilla-Silva (2004) explains that Latin American countries have a tri-racial system, in which an intermediate group buffers race conflict. Luisa Schwartzman (2007) also claims that, in Brazil, "browns serve as a buffer zone between blacks and whites" (p. 944).

\section{Whitening}

A related process that scholars argue tones down race conflict is whitening. There are three ways that whitening can occur: (1) Intergenerational whitening is when a black person and a white person have a child, and the child is considered whiter than the black parent. (2) Social whitening is when a person is born black, but through an increase in class status, is considered white or whiter in some situations. (3) Cultural whitening is when a person is born Indian, yet acculturates to the dominant culture and becomes white or whiter in some situations. Intergenerational whitening can refer to blacks or Indians; social whitening is more commonly used to discuss people of African descent; and cultural whitening is more commonly used to describe processes of incorporation for people of indigenous descent. The whitening process works at the level of practice and ideology; people hope to "improve the race" through marrying lighter-skinned partners, and the governments of many Latin American countries have promulgated mestizaje (racial and cultural mixture) for the purpose of whitening the nation (Graham 1990; Skidmore 1993).

The possibility of whitening is dependent on a definition of race that is not based solely on color or descent, but on other changeable factors. Many scholars contend that, in Latin America, race is not always based solely on color or descent, but that social and cultural characteristics also come into play (Rodríguez 2000). Jorge Duany (1998) argues that in the Caribbean, "[p]henotype and social status rather than biological descent define a person's racial identity" (p. 150). And, Nancy Landale and R. S. Oropesa (2002) posit that in Latin America, "definitions of race are more fluid and ambiguous than is the case in the United States" (p. 233). According to these scholars, the lack of rigidity in racial classifications allows a person to change their racial status in Latin America.

Social Whitening. Scholars of Afro-Latin America have argued that blacks can be whitened through a change in social status. Winthrop Wright (1990), for example, claims that in Venezuela, "when a black escaped poverty, he or she ceased to be socially black" (p. 10). Wright goes on to 
explain that "[o]ccasionally, financial and political success socially whitened black Venezuelans. For them and their white counterparts, clothes, education, language, social position, and the accumulation of wealth combined to make an individual whiter in the social context" (p. 10). Wade (1993) argues that, in Colombia, the trope "money whitens" does not mean that very darkskinned people are actually classified as white, but that "rich black or mulatto people are treated as if they were white (or nearly white)" (p. 339).

Cultural Whitening. Studies of Peruvians of indigenous descent indicate that classification with labels such as cholo, indio, or mestizo is not determined by skin color, but by cultural factors, including geographical origin and social standing (see Bourricaud 1975; de la Cadena 2000; Van den Berghe 1974; Varallanos 1962). As indigenousness is conceptualized in Peru, a person with brown skin and black hair could be labeled as white (blanco) or Indian (indio), or either of the two intermediate labels: cholo or mestizo. ${ }^{2}$ According to these studies, what determines one's racial status is not skin color, but level of education, cultural markers such as language and dress, and geographic and class location. In Peru, descendants of indigenous people can change their racial status from indio to mestizo by abandoning indigenous cultural forms, obtaining a formal education, and migrating to the coast (as this entails leaving highland Indian villages). Highly educated Peruvians are considered white and acculturated Indians are considered mestizos. Recent work on indigenous identities in Peru contests the simplicity of this framework, yet these studies do not address the absence of African-descended Peruvians from these discussions, nor do they dismiss the idea of cultural whitening for Indians (de la Cadena 2000; García 2005; Weismantel 2001).

Intergenerational Whitening. Scholars of race in Latin America have found evidence of intergenerational whitening in Brazil and Colombia. One study found that highly educated nonwhite Brazilians are more likely to label their children white than their less-educated counterparts (Schwartzman 2007). Data limitations did not allow Schwartzman (2007) to discern whether this is because class status directly influences racial self-identification, or because higher-class brown Brazilians are lighter in skin tone, and thus closer to the boundary between white and brown, which facilitates their "boundary crossing." Research by Wade (1993) in Colombia and Edward Telles (2004) in Brazil would support this latter claim, as they argue that only racially ambiguous people have the option of shifting racial categories.

\section{Bipolar vs. Continuum}

When discussing how people of African and European descent are classified, scholars frequently contend that the United States is marked by a "rigid bipolar" construction of race, whereas Latin America has a "racial continuum based on phenotype" (Safa 1998:4-5). Wade (1997) states that, in Latin America, there is a continuum and that "only people who look quite African in appearance will be identified as black" (p. 14). Clara Rodríguez (2000) explains that, in the United States, racial categories are "few, discrete, and mutually exclusive," yet, in Latin America, there are "many, often overlapping categories" (p. 9). Livio Sansone (2003) claims that throughout Latin America, we find "a color or racial continuum, rather than a polarized system of racial classification" (p. 8). These scholars concur that, in Latin America, black is a relatively narrow category used to refer to only a small portion of the descendants of African slaves and that there are a variety of other classifiers used to refer to people who are "neither black nor white" (Degler 1986). They contrast this system with the United States, where black is a wide category used to refer to people of a variety of skin tones.

2. In Peru, cholo refers to a person of indigenous descent who does not live the peasant lifestyle associated with indigeneity in Peru. Mestizo refers to a person of indigenous descent who shows signs of either cultural or biological mixture with people of European descent. Mestizo is a more polite term than cholo. 
More recent scholarship, however, contests these generalizations and posits that bipolar conceptions of race also exist in Latin America, alongside color continuums. Robin Sheriff (2003), for example, points to the colloquial expression in Brazil: "If you do not pass for white, you are black," as well as other evidence to argue that many Brazilians see white and black as separate categories, with no intermediate category in between. Sheriff posits that Brazilians use a variety of race/color terms, such as moreno, mestiço, and mulato, not as intermediate categories between black and white, but as a way to avoid the more loaded term, "negro."

In the remainder of this article, I explore the extent to which these ways of thinking about race are useful for understanding the African-descended community where I conducted research. First, I provide background information on people of African descent in Peru and describe the data collection process. Then, I draw from these data to argue that, if we consider race and color to be conceptually distinct, there is no mulatto escape hatch, no social or cultural whitening, and no continuum of racial categories in the African-descended community I studied. In the conclusion, I discuss the implications of these findings.

\section{Background and Methodology}

\section{People of African Descent in Peru}

Blacks in Peru are concentrated on the coast because of the political economy of coastal agricultural production. Between 1528 and 1821, more than 100,000 African slaves were brought to Peru to meet labor needs, principally for coastal agriculture (Hünefeldt 1994). Although the native indigenous population was the major source of labor in highland mines, attempts to use the indigenous population for coastal agricultural production were generally catastrophic, and hastened the destruction of indigenous coastal peoples. ${ }^{3}$ On the northern Peruvian coast, laborers often constituted a mix of contracted yanaconas (paid Indian laborers), mitayos (obligatory Indian labor), slaves, and free blacks (Aldana 1989; O'Toole 2006). At several points in Peruvian history, because of relatively high rates of manumission, free blacks outnumbered enslaved blacks (Bowser 1974; Cuche 1981).

Peru shares with many Latin American countries the historical presence of a large class of free blacks. ${ }^{4}$ Peru differs, however, in one important way from the countries where the vast majority of studies of Afro-Latin America have been undertaken. Most of these studies have been conducted in countries with a history of large scale plantation slavery, and thus a much larger percentage of the population descended from African slaves. Unlike Brazil, Puerto Rico, Colombia, the Dominican Republic, Cuba, and Venezuela, Peru has a relatively small Africandescended population and a sizeable indigenous population. Peru imported fewer African slaves than these countries. In addition, Cuzco, Peru was the seat of the Incan empire, and Peru's indigenous population has been and continues to be much larger than these countries. ${ }^{5}$

There are no official statistics on race in Peru. However, a reasonable estimate would be that the Afro-Peruvian population is between 5 and 10 percent of the population, and the indigenous population is about 40 percent of the population. African-descended Peruvians are concentrated on the coast, and indigenous people in the highlands. The coastal populations

3. The north coast and valleys of Peru were once home to large indigenous populations, such as the Chimu, Sicán, and the Incas (Hocquenghem 2004). However, the Spanish policy of removing Indians into reducciones combined with the destruction of indigenous populations through warfare and disease left much of this region depopulated in the sixteenth century (Hocquenghem 2004; Schlüpmann 1991). For Spaniards and criollos (Peruvian-born Spaniards), this translated into an opportunity to form haciendas in the depopulated fertile valleys in northern Peru.

4. Free blacks include blacks who were manumitted and the descendants of freed blacks. Nearly all Africans who came to Peru during slavery were enslaved.

5. For a more in-depth discussion of the racial geography of Afro- and mestizo-Latin America, see Sue and GolashBoza (2009). 
primarily live in large cosmopolitan cities, yet many people reside in towns and villages that dot the 2,414 kilometer coast of Peru. Most of these towns and villages are made up of indigenous and mestizo people, with few or no blacks. According to researchers at the Afro-Peruvian nongovernmental organization (NGO) Centro de Desarollo Etnico (CEDET), the largest concentration of blacks in Peru is in Lima, and there are about 50 villages on the coast of Peru that have a substantial Afro-Peruvian presence. With their guidance and contacts, I visited 12 of those villages, and chose Ingenio as the site of this research. Although I was not working for CEDET as I conducted research, people in Ingenio often associated me with CEDET and other black Peruvian NGOs that occasionally host events in Ingenio or nearby Morropón. In formal interview settings as well as whenever asked, I explained to villagers that I was a university student working on a thesis about blacks in Peru.

\section{Site Description}

The findings presented in this article are based on qualitative research in Peru, both in Ingenio and Lima. Ingenio is a small village in northern Peru, in the province of Morropón, and in the state of Piura. According to local leaders, Ingenio is about 85 percent African descended. The other villagers are either primarily of indigenous descent or primarily of European descent. Ingenio is one of several villages in Piura that sits on or near an ex-hacienda and therefore has a substantial Afro-Peruvian presence.

Ingenio has about 300 houses and lies at the foothills of the Andes. The local economy in Ingenio revolves around the production of rice for the national market. Most families own a plot of land; the average landholding is about 3.5 hectares and the person with the most land has around 10 hectares. There is some inequality of means in the village, yet there is not enough diversity to create a class hierarchy, at least not in the way James Scott (1987) describes in a Malaysian village, where some villagers are known as "the rich" and others as "the poor." In Ingenio, some people have more access to consumer goods than others. At the extremes, there are a couple of older villagers who live almost entirely outside the cash economy, and there are two families that each own one piece of large machinery, namely a truck and a tractor. In addition, there are about ten families that own motorcycle taxis, and young men use these as means of earning money by transporting villagers who can afford the 2 soles (about US\$ .75) for transportation to Morropón, about seven kilometers away.

The name, Ingenio, derives from the chimney in the center of town formerly used to burn sugar cane. Ingenio is the former seat of the Hacienda Buenos Aires. The Hacienda Buenos Aires produced sugar cane and rice between 1872 and 1972. The majority of the workers on the Hacienda Buenos Aires were the descendants of African slaves, with the remainder being descendants of Spaniards and indigenous people. The Hacienda Buenos Aires itself never employed slaves, as slavery ended in Peru in 1854, nearly two decades before the Hacienda Buenos Aires was formed. In 1972, the former hacienda workers formed an agricultural cooperative and became collective owners of the land. The cooperative continued until 1983 , when the workers decided to split their landholdings, such that each member of the cooperative received 3.5 hectares of land.

\section{Research Methodology}

I lived in and conducted participant observation in Ingenio for nine months and in Lima for another nine months. I carried out 50 semi-structured interviews in Ingenio and 30 in Lima. In addition, I did eight follow-up interviews in Ingenio, drawing from "collaborative ethnography" techniques (Hinson 2000; Lassiter 2005). I carried out this research over five years, from 2002 to 2007. All of the interviews were conducted in Spanish, the interviewees' native language. In Ingenio, I located interviewees by establishing relationships with people in the village. That way, the interview was not our first conversation. In Lima, I interviewed 
relatives of people I had interviewed in Ingenio, in addition to asking interviewees in Lima to refer me to others from Ingenio.

In my interviews in Ingenio, I did not ask people directly what their race was, or if they considered themselves to be black, as I wanted to gain an understanding of local systems of classification. As such, I asked, "People in Ingenio refer to me as blanca, how do you think they refer to you?" Through this discussion of race and color labels, I probed interviewees about labels they offered. Towards the end of the interview, I asked interviewees more direct questions about the most common labels I had culled through my ethnography-negro, cholo, blanco, zambo, and moreno. I also asked about the label mestizo, since it forms part of the official discourse, but most people were not sure what mestizo refers to.

In Lima, I asked questions that allowed me to understand how migration to Lima affects the identity of people from Ingenio. Specifically, I considered whether or not better wages, access to amenities, and a cosmopolitan environment influence patterns of racial identification among people from Ingenio. Comparing the use of race and color labels of people in Ingenio with those used in Lima provides a way to gauge the extent to which African-descended Peruvians can experience social whitening, as migration to Lima nearly always leads to upward mobility for residents of Ingenio.

I was granted permission to record all of the interviews I conducted. I transcribed and coded the interviews while I was in Peru. This allowed the analyses of my interviews to inform my ethnography both in Ingenio and in Lima. Coding consisted of selecting themes that emerged from the interviews and categorizing interview excerpts according to these themes.

\section{Conceptualizations of Race and Color in Ingenio and Lima}

In Ingenio, the most common race and color labels were blanco, trigueño, moreno, and negro, from lightest to darkest. As usages vary, I will first explain the local meaning of each of these labels. Only negro and blanco can be directly translated into English, as black and white, respectively. The other terms do not have English equivalents. Negro shares a common root with the English word, negro, and, like black, negro can be used to refer to inanimate objects such as cats or cars that are black in color. In Peru, blanco is used to refer to people who are very light skinned, and not necessarily only to people who have exclusively European ancestry. Similar to white, blanco can be used to refer to objects. The other two labels refer exclusively to people, not inanimate objects. Moreno could be translated as either black or brown, and is used in Peru to refer to people who have dark skin, usually accompanied by some evidence of African descent, such as facial features or hair texture. Trigueño can be literally translated as wheat colored, and it occasionally was invoked in my interviews in both Ingenio and Lima to refer to people of African descent with very light skin. Trigueño is also used in Lima to describe people who have European and indigenous ancestry and tan skin.

I will also make brief mention of two labels that refer more to hair texture than skin colorcholo and zambo. Zambo derives from colonial classifications, and historically has referred to the progeny of black/Indian unions. However, in Ingenio, zambo was used to refer to people who had very curly or kinky hair. It was used in opposition to cholo, which referred to people with very straight hair, usually Indians. Cholo nearly always was used to refer to indigenous people from Bajo Piura, and had physical as well as cultural connotations. It is worth pointing out that I rarely heard the labels mestizo or mulato mentioned in the course of this research.

\section{Mulatto Escape Hatch?}

In Ingenio, the word mulatto has fallen into disuse. There is evidence that this label was used during the colonial period in Peru to refer to the offspring of blacks and Spaniards, and mulattos were perceived differently than blacks and Spaniards, as evidenced in the mulatto 
figure, Jose Manuel, in the book Matalaché (1928), written by Enrique López Albújar. The author is from a town very near Ingenio, called Morropón. Matalaché is a novel about a mulatto slave in Piura, Peru who falls in love with the white daughter of his master, and is killed by his lover's father. In this text, José Manuel is arguably an intermediary figure insofar as the author portrays him as superior to other blacks, yet not good enough for the master's daughter. Mulatto, however, does not form part of the local parlance in Ingenio today. The very few times I did hear this word used, it was to refer to someone who was very dark skinned. Today, "mulatto" does not serve as an intermediary category between black and white. There are, however, other contenders for the intermediary category-moreno, trigueño, and zambo.

To determine whether or not there was an intermediary category that served as a buffer group between blacks and whites, I consider how my interviewees in Lima and in Ingenio used the labels negro, moreno, zambo, and trigueño to describe people. An analysis of these labels reveals that there is not a buffer group between negros and blancos in this community because the intermediary labels refer to color and not to race. As discussed above, color labels are not group classifications; they are individual descriptors.

Is Moreno an Intermediary Category? Moreno and negro were used interchangeably. This indicates that they are not mutually exclusive categories. My interviewees often made references to both the raza morena and the raza negra in the same sentence to talk about the same group of people. Some of my interviewees pointed out that negros and morenos are of the black race. For example, Roberta, a woman who self-identified as morena and negra, said to me, "mi papá ha sido así moreno, zambo. Ha sido negrito, zambo" (My father had been moreno, zambo, like that. He had been negro, zambo.") The way that Roberta phrased this indicates that negro and moreno are synonyms. Her wording also indicates that moreno and negro are color descriptors, as she is describing her father, not placing him in a particular category.

I asked my interviewees in Lima to clarify the difference between negro and moreno for me. Consider this dialogue between myself and two young people from Ingenio, who now live in Lima. I was interviewing Mirella, a young honey-colored woman with long curly locks who had come to Lima to work as a nanny. We were in Fiorela's room, and she also participated in the interview. Fiorela also works as a domestic, is the color of cinnamon, and has long, tightly curled hair.

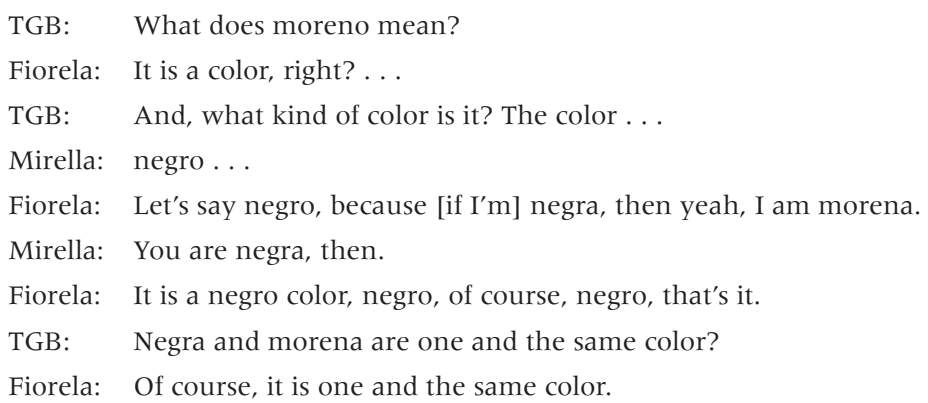

Fiorela and Mirella both tell me that moreno is a color, and that moreno and negro are the same color. In this dialogue, they are using moreno and negro to refer to color. I then ask questions to see if moreno and negro are mutually exclusive groups.

TGB: $\quad$ Any person who is morena is also negro?

Mirella: Of course, because there are morenos that are called negros or, negros that are called morenos.

TGB: But, is there a difference? Are there people who say, I am morena, but I am not negra?

Mirella: There are people who say that. 
TGB: $\quad$ But, is it false, or no, it's true?

Fiorela: For me, it is false.

Mirella: Of course, because ...

Fiorela: Sometimes, when I walk by, they call me "morena" and . . . other times they call me "negra," but I don't get offended. I have thought about this, and if they call me morena and negra . . .

Mirella: It's the same.

Fiorela: It's the same, one and the same color.

I had interviewed Fiorela the week before and had asked her about the meanings of moreno and negro. Thus, her reflection may well be a product of my questioning her about issues she had not heretofore considered. Nevertheless, after considering this, Fiorela concluded that negro and moreno mean the same thing, and Mirella agreed. Later in the interview, I asked them again if negro and moreno meant the same thing, and Mirella responded: "si salimos morenos es porque venimos de negros ¿di?, ni modo que vamos a venir de blancos." ("If we come out morenos it is because we come from negros, right? No way that we would be coming from whites.") Here, Mirella is invoking descent, and contrasting both negro and moreno with whiteness. This means that she sees negros and morenos as belonging to the same group, a group that clearly is not white. In addition, by mentioning descent, Mirella is assigning a group-based identity to blackness, distinct from a color descriptor.

Janelly and Lorena also told me that morenos are part of the black race. Janelly, a woman the color of coffee in her late teens who recently had moved to Lima from Ingenio, told me that morenos are part of the black race. When I asked what moreno means to her, she responded: "que somos negritos, pues, que somos de raza negra." (That we are black, that we are of the black race.) Her response implies that she sees morenos and negros as belonging to the same (black) race and that moreno and negro refer to the same group-based identity. I heard a similar response from Lorena, a housewife in her forties who lives in Lima, and is the color of milk chocolate. Lorena self-identified as morena, yet then told me that not only is she part of the black race (la raza negra), but also that her children, even if they are not very dark skinned, are also part of the black race.

As a final example of this, we will consider Vicente's responses, as he used negro as both a color and a racial label. When I asked Vicente, a construction worker from Ingenio in his forties, what it means to be black, he used black in a racial sense, although without invoking the word race in this excerpt. At other times in the interview he pointed out that there is a white race and a black race.

TGB: $\quad H e r e$ in Peru, people would say that I am white. How would people refer to you?

Vicente: People call me, more so call me negro.

TGB: $\quad$ And, what does negro mean to you?

Vicente: Well, for me, negro is a color that really is, as they say, so beautiful that it has no comparison. And, I feel proud because, really, it is an appealing color. And, I have no reason to be offended by what I am.

TGB: And, if you see another person who also is negro, do you feel any brotherhood or camaraderie with them?

Vicente: Actually, I call other morenos familia. Most people from Chincha ${ }^{6}$ call each other familia.

6. Chincha is a place south of Lima that is associated with Afro-Peruvians. Vicente is from Ingenio, not Chincha. His indication of solidarity with people from Chincha provides evidence that he sees himself as part of a black racial group. 
TGB: $\quad$ Moreno and negro mean the same thing?

Vicente: No, they are more, well, here, we distinguish by color, because there are some that are very mulatto $^{7}$, negro mulatto nearly blue, and I am more so moreno.

In the above comments, Vicente strongly identified as negro, and referred to negros as belonging to a fictive family, indicating a group-based identity. He also associated positive traits with blackness. Nevertheless, he described himself as moreno, in contrast to others who are darker than him. In this sense, he was using negro as a racial label, and both negro and moreno as color labels. Negro qualifies as a racial group in this case, since Vicente used negro to refer to heritable traits that have a cultural element, and he identified with this group in the collective sense (Smedley 2007). Vicente also, like other interviewees, used moreno and negro interchangeably on some occasions. This can be seen when I asked him about negros and he responded with regard to morenos.

Vicente distinguished between colors, and pointed out that he is not as black as other blacks, and thus is actually moreno. Vicente used moreno as a label that identifies a brown skin color, but that does not mean he sees moreno as a separate group from negro. He in fact emphatically defined himself as negro and then went on to point out that his skin color is not black, but brown. Vicente and Lorena's insistence that they are morenos and not negros in terms of skin color is reflective of the idea that it is better to be brown than black skinned. It is also a point of fact-they are not as dark as some blacks. There were some people, however, that did refer to themselves as negros. For example, there is a woman in Ingenio whose skin is the color of dark chocolate, who has kinky hair, and is known around town as "Señora Negra." When I spoke with her, she described herself as negra, and told me that she prefers to be called negra, and not by her name.

Vicente and Mirella also insisted that they are not ashamed of being black, without me asking them a question that would seem to provoke that response. I simply asked them what black means to them. Their responses indicate that they were aware of negative connotations associated with blackness, yet chose not to believe them. As Vicente's and the other cases make clear, some Peruvians who self-identify as black or moreno understand blackness as both a color and as a collective group. Since morenos are part of the collective group, black or negro, moreno cannot be an intermediate racial group.

Are Trigueño and Zambo Intermediary Categories? Although moreno was the most likely candidate, it will be worthwhile to consider other contenders for the intermediary group, trigueño and zambo. In an interview, Jeremy, a young man who does not appear to be of African descent who works in a garment factory in Lima, told me that he has black blood and black family members, yet that his skin color is trigueño. His mention of consanguinity indicates that he saw himself as a member of the black racial group, but that his color is trigueño.

Similarly, I had a conversation with a woman named Olga in Ingenio whose sandy skin led others to label her as white. However, when I asked her if she was white, she said "yo no soy tan blanca" (I am not that white). Then, I asked her if she considers herself to be black, and she said that she does. She also described herself as zamba, due to her tightly curled hair. In general, zambo or zamba were used to describe hair texture, and a person could be light or dark skinned and zambo. Since some zambos are negro in color, others are morenos, and still others are trigueños or blancos, zambo could not be an intermediary category. Likewise, villagers used trigueño to describe the color of people they also considered to be negros. The fact that villagers do not use these categories in a mutually exclusive fashion indicates that they are color, not race descriptors, and that there is not an intermediary racial category between black and white. There is no mulatto or other escape hatch.

7. Mulato (mulatto) in Ingenio does not refer to the descendant of a white and a black person. Mulato was used by people to refer to a very dark black person. 


\section{Whitening-Social, Cultural, and Intergenerational}

In this section, I explore the extent to which social, cultural, and intergenerational whitening are possible. The possibility of whitening in Latin America is predicated on the idea that "definitions of race are more fluid and ambiguous than is the case in the United States" (Landale and Oropesa 2002:233; Rodríguez 2000). This fluidity allows for the possibility of change from one category to another over the course of one's life. It is not just U.S. scholars who take this position. In an August 29, 1999 article in the prestigious Limeño newspaper, El Comercio, a Peruvian scholar, Alejandro Ortiz, argued that in the United States, he who is born black, dies black, whereas in Peru, your social status can change your racial classification.

If someone could become less white by virtue of an increase in social status or a change in cultural attributes, this would require that race or color classifications not be fixed. In order to discern the extent to which blackness in Peru is fixed or fluid, I asked interviewees in Lima if a black person could become white. Below is an example of Fiorela and Mirella's responses to this question.

TGB: If a black person from Ingenio comes here to Lima, this person continues to be black, or can become white?

Mirella: There, no, hahaha.

Fiorela: Unless they are Michael Jackson, hahaha.

Mirella: If I color myself, haha.

TGB: $\quad$ Haha, so, for you, Michael Jackson ...

Mirella: If I was born black, black I have to stay.

Fiorela and Mirella find it laughable that a black person could become white. In this excerpt, they are using blackness as a color, and mention how Michael Jackson changed his skin color. Neither Mirella, Fiorela, nor any of my other interviewees mentioned financial status in connection with whiteness. In their view, Michael Jackson has been whitened due to skin bleaching, not his phenomenal wealth. Despite the fact that people in Ingenio and in Lima generally agreed that migration to Lima involves a relative improvement of one's socioeconomic status, I did not interview anyone in Lima who indicated that they had become less black by virtue of moving to Lima, even if they did mention that their financial status had improved. I also directly asked people if it were possible to become less black by moving to Lima, and most people gave similar responses to Fiorela, that if you are born, negro, negro you will remain. When discussing blackness as a color, some people did say that you could become physically lighter because the sun is not as harsh in Lima as it is in Ingenio. These people said that one could become less black, but that they would not become white or mestizo. However, this would not be social whitening, but physical lightening, a change in color gradation. In order for racial classifications to be fluid for African-descended Peruvians, these classifications would have to be based on social or cultural characteristics that can change over the course of one's life, not on fixed characteristics such as descent or color. As seen in Renata's comments below, blackness is not something that can be changed.

TGB: If a black person comes here to Lima from Ingenio, can they become white or mestizo, or will they always be black?

Renata: No, no, there can't be a change. That is our origin, our nature, there won't be a change, even if we bleach our hair, no, no, ha ha ha. Even if we dye ourselves, no, that is our race, our origin. No one can take that away; it does not change.

In this excerpt, Renata is using black as a racial category, insofar as she focuses on race and origin. The interview excerpts in this section point to the fact that people from Ingenio generally see blackness as a fixed quality that does not change over the course of one's life. Thus, racial and color classifications are not fluid for my interviewees. The lack of fluidity 
makes social and cultural whitening unlikely. In the remainder of this section, I explore social, cultural, and intergenerational whitening more specifically.

Social Whitening. Social whitening refers to the process whereby an improvement in social or class status results in a person being classified as white, or whiter. If social whitening were a possibility for blacks in Peru, we would expect that blacks from Ingenio who migrated to Lima would become less black as a result of their consequent increase in social status. Migration to Lima means entry into the cash economy, and nearly all migrants in Lima had more access to cash and consumer items than those left behind.

To assess the social whitening prospects for migrants in Lima, I compared the use of race and color labels by my interviewees in Ingenio with those in Lima. Charles Gallagher (2000), Ruth Frankenberg (1997), and bell hooks (1989) agree that, in the United States, whiteness is an unmarked status. To be white means that one can either safely ignore race (hooks 1989) or decide for oneself what whiteness means (Gallagher 2000). In the United States, whiteness is also a gendered status that implies racial purity. Richard Dyer (1999) argues that the equation of whiteness with the Virgin Mary in the Western world implies that white women are imagined to be the pinnacle of purity and cleanliness. ${ }^{8}$ To determine whether or not black Peruvians can become white, I asked my interviewees what their racial categorization means to them. If it seemed they would prefer to dispense with their black group identity, then that could indicate that they wished to become white, to become ethnically or racially unmarked.

Most interviewees in Ingenio said that blackness refers above all to skin color. For example, when I asked Mariana, a young single woman the color of cacao why people called her negra she said it was because she was morena. Then, when I asked her what negra means, she said it refers to color. I asked if it had any other meaning, and she said that it did not.

In contrast, interviewees in Lima were more likely to give blackness a more politicized tinge. The interview excerpts below reveal that my interviewees in Lima displayed more attachment to their black group identity than did my interviewees in Ingenio. The first example is Dariel, a 20-something man the color of milk chocolate who works in a clothing factory in Lima. Dariel considers himself to be black. He uses negro and moreno interchangeably, and says that he finds morenos to be attractive.

TGB: $\quad$ Does being black have any meaning for you?

Dariel: $\quad$ Being black has meaning. Yes, for me, yes because, now, all morenos are, perhaps for me have something appealing about them.

Dariel's remarks that his blackness is meaningful to him contrast with responses given by my interviewees in Ingenio, who often responded that being black just means having dark skin. Gustavo, a young man who works in carpentry, also indicated that his blackness is meaningful to him. His statement that he does not feel either superior or inferior to whites indicates that he is aware of discrimination, yet refuses to internalize it. As the following quote demonstrates, Gustavo is well aware of his status as a black man.

Gustavo: Because, what the white does, I do, and what the black does, the white can do, because we are all equals, we are all the same. The only difference is the skin, nothing else, the color, as they say, right?

TGB: $\quad$ The color, but is there more discrimination here for blacks than for whites?

Gustavo: Yes, here, yes.

TGB: Why? How does it work?

8. There are other meanings of whiteness, such as access to privilege and resources. However, the question addressed here is whether or not access to material goods renders a person whiter. Using that definition would thus be circular. For this reason, I focus on other meanings of whiteness, and argue that being racially or ethnically unmarked is functionally equivalent to whiteness. 
Gustavo: Well, I am not going to feel inferior to others just because I am black, right? No. The truth is that I feel neither inferior nor superior. I feel equal, normal.

People in Ingenio often did not invoke such a politicized definition of blackness, except in those cases where they had been to Lima, or had been active in the Afro-Peruvian social movement. A comparison of two women-one who lives in Ingenio and one who lives in Lima-demonstrates this contrast. Georgina, a young mother of a three-year-old boy who lives in Lima and has worked as a domestic employee, but is presently unemployed, began the interview lamenting her current financial situation. She told me she left Ingenio before finishing high school because her parents fought a lot, and she saw no other choice. Upon arriving in Lima, she found a job, but it paid less than half the minimum wage for more than 12 hours of work. Now, she doesn't work, and her partner barely makes enough for them to get by. This is exacerbated by his drinking problem. Her life contrasts with Alexandra, who was born in Ingenio, married a baker in town, and their business is sufficient for the whole family to eat well. Alexandra rarely leaves town, as she and her husband are open for business every day. Alexandra has two sons, whom she described as "morenito" and "zambito."

Alexandra's understanding of race is depoliticized. She freely uses color terms to describe her family members, but does not render these labels meaningful beyond descriptors. She is not aware of her own ancestry nor the history of African slavery in Peru. When I asked her if she had ever been discriminated against, she recounted to me a story of a boy who had disrespected her husband, and with whom she had had a few negative encounters. There was no racial undertone to these events. When I asked her how she describes herself, she responded "zamba," and told me that was because her hair is tightly curled. I also asked her what moreno, blanco, and negro meant, and she told me that they are color descriptors. Alexandra had never heard of the Afro-Peruvian social movements, and did not see being black as cultural production. She did, however, say that sometimes, calling someone negro can be offensive, although she thought people were being overly sensitive if they were offended by that, as it is simply a descriptor.

Georgina, in contrast, was aware that racism is a problem in Peru. When I asked Georgina if her boss had ever offended her because of her skin color, she responded that she had not experienced racism, but that her boss sexually harassed her. Unlike Alexandra, she offered up the word "racism" to describe what it would have meant for her boss to mistreat her for being black. Then, Georgina told me that in Ingenio, people can have relationships with whomever they please, whereas in Lima, people have criticized both her and her husband because she is black and he is not. She also told me that sometimes she is offended when people call her black, but that it depends on the context, and how they say it.

TGB: $\quad$ Has any ever offended you because of your skin color?

Georgina: I think so, but I haven't paid them any attention.

TGB: What did they say, for example?

Georgina: Ugly negra, zamba. No, they don't offend me if they say that . .

TGB: $\quad$ Do people say negra in an affectionate way, or more so in an offensive way?

Georgina: My husband calls me negra affectionately, and I don't get offended because of that. And, if they just call me negra in the street, I don't get offended. I don't get offended anymore.

TGB: $\quad$ Does it depend on how they say it?

Georgina: Of course ... At the market, one of my friends calls me "negrita," and it doesn't bother me. Why would I get mad if I am black? No, for what? I am proud of my color, and everyone would like to have this color, don't you think?

Georgina, because of her experiences of discrimination in Lima, attributes new meaning to her blackness. She indicated that she is proud to be black, and later in the interview, said that everyone should be proud of their color, since that is who they are. She also said she doesn't 
get offended "anymore," indicating a change in her sense of self. Instead of downplaying her blackness, Georgina's experience of migration has given her blackness new meaning.

A comparison of Georgina's, Gustavo's, and Dariel's comments to those made by people in Ingenio indicates that some people's racial consciousness is increased through migration to Lima and consequently experiencing new forms of racial discrimination, as opposed to attributing less meaning to their blackness, or rejecting their ethnic identity. Thus, if we understand whiteness to mean having an unmarked identity, it is clear that migration to Lima is not a whitening process for people from Ingenio. In contrast, migrants in Lima are more likely to develop a group-based identity as black than those who remain in Ingenio. The data presented in this section indicates that social whitening does not appear to be a possibility for blacks from Ingenio.

Cultural Whitening. Cultural whitening refers to the process whereby acculturation allows a person to be classified as white, or whiter. In Peru, scholars have contended that Indians can become mestizos or even white through acquiescence to the dominant culture. Marisol de la Cadena (2000) argues that, in Peru, whiteness is a status that implies cleanliness and moral decency, and does not entail a "white" skin color. In Peru, like the United States, whiteness is construed as the superior racial category. However, unlike in the United States, in Peru, indigenous people can become white by virtue of adopting dominant cultural forms and attaining an education (Bourricaud 1975).

In Peru, whitening through acculturation is not possible for blacks, as they generally participate in dominant cultural forms. For example, criollo music, food, and dance are cultural forms associated with coastal whites and blacks. Blacks are seen as the "authentic" producers of these criollo cultural forms, and criollo culture is the dominant culture. For example, domestic workers from Ingenio told me that their employers preferred them to indigenous women, as they already knew how to cook criollo foods and were accustomed to criollo culture and language. So, there is not a way for blacks to acculturate and to participate in dominant cultural forms, given that blacks are already the producers of cultural forms associated with Peruvian-ness.

Intergenerational Whitening? Many of my interviewees used a descent-based definition of blackness, which indicates fixity, not fluidity, of the black group, even across generations. One example of this is a woman named Yraida. Yraida is in her thirties, and has been a cook in a wealthy household in Lima for about 15 years. Yraida described her father as white, her mother as black, and herself as black. When I asked her about her self-description as negra, she responded: "Sí, soy negra, sí. Pero, sé que tengo sangre serrana, pero sé que soy negra, pero con sangre serrana." ("Yes, I am black, yes. But, I know that I have mountain blood, but I know that I am black, but with mountain blood.") Yraida is using serrana here to refer to her white father, since, in Ingenio, being from the mountains is associated with whiteness. It is noteworthy that Yraida invokes race or blood when referring to both her serrana ancestry and her black ancestry, and that she gives primacy to her black ancestry. In the following conversation, she describes herself as both negra and morena, and contrasts these terms with whiteness.

TGB: How would people describe you?

Yraida: Me, they would call me negra ...

TGB: And, what does negra mean to you?

Yraida: Negra, negra race, well, that I was a slave, that I was, I don't know, negra, that I was not white...

Yraida insists she is not white even though she describes her father as white. This is similar to a U.S. discourse of hypodescent, where black ancestry trumps white ancestry. It is also important to note that Yraida is quite certain of her racial classification, of her belonging to 
the raza negra. This contradicts Suzanne Oboler's (2005:84) claims that in Peru, "one drop of white blood makes you white," and that "the ideology of blanqueamiento [whitening] has 'confused' ... Peruvians' racial identifications." Yraida does not appear the least bit confused, nor does she subscribe to the whitening ideology. As Yraida sees her blackness as based on her ancestry, it is unchanging, even across generations.

\section{Bipolar or Continuum?}

In Ingenio, people use a variety of labels to describe others' skin color and hair texture. In this section, I argue that not all of these labels are racial classifications, insofar as they do not refer to mutually exclusive groups of people thought to share physical and cultural traits and a common ancestry. The only two categories that fall into this definition are black and white. The other labels are descriptors, and do not refer to collective groups. Therefore, there is not a continuum of racial categories, but a continuum of color labels.

I will first establish that negro is used as a racial label in Ingenio. In my participant observation, people often referred to themselves, to their family, or to the whole town as a black town. In many cases, villagers would use the descriptor negro as a racial label, meaning that they would contrast it with white. I will explain one instance in which this occurred at a cockfight. Cockfights are a frequent source of entertainment in Ingenio. Whenever there is a cockfight, villagers from a neighboring town bring their roosters to compete with the local roosters. On one occasion, the competing cockfighters came from a town a few hours up the road, well into the highlands. Like many of the people in the northern highlands of Peru, some of the visitors had blond hair and blue or green eyes. I asked Mariana where the competing cockfighters came from. Mariana told me that they had come from the mountains. I asked her if the people in the sierra were white, as I had noticed a lot of the vistors were white. She laughed, and said, in reference to Ingenio, "sí, porque aquí hay puros negros" (yes, because here there are only blacks). The other women near us nodded and chuckled in agreement.

On another occasion, my brother came to visit us in Ingenio, and brought his nine-monthold son with him. Perla and her family came to welcome them upon their arrival. Perla and her children, both the men and the women, all wanted to hold my nephew, Dante, who has blond hair and blue eyes. Tired from a long trip, and puzzled by the new faces, Dante became a bit fussy. At that point, Perla said that Dante must be thinking “iquiénes serán esas negras feas?" (Who are these ugly blacks?), referring to herself and her family members. She and her children laughed at this, and continued to entertain Dante. In both of these situations, villagers were using blackness in a way that could be construed racially, insofar as they were contrasting blackness with whiteness. This suggests that blackness and whiteness are seen as mutually exclusive descriptors of people.

In some cases, people used black to refer to color. One afternoon, I was walking around Lima with Fiorela. We were on our way to the market to purchase some things we needed to make lunch. Fiorela and I were talking about life in Ingenio. She mentioned that, when she goes to Ingenio and stays in the sun for too long, "me pongo bien negrita," ("I get very black.") She laughed after saying this. By saying that she gets black, Fiorela is using black as a color identifier. Her laughter after saying this is akin to Donna Goldstein's (2003) suggestion that much racial signifying is done through coded, joking language. By laughing after saying that she gets black, Fiorela smoothes over the negative connotations that go along with the label black, and the widespread belief in Peru that it is better to be light.

Not all labels that describe people can be considered race or color labels. Labels may, for example, be used to refer to one's size-corpulent or slender. In Peru, people commonly call one another gorda (fat); flaco (slender); ojona (big eyes); and other similar labels. These clearly do not refer to race, as they do not form part of the "real and sometimes imagined somatic cultural characteristics" that people see when they think they are seeing race (Miles and Torres 1999:32). 
People used lacio, trinchudo, and cholo to describe straight hair, and enrulado, zambo, and nuto to describe curly or kinky hair. Only zambo and cholo were used as nouns to refer to people, whereas the other descriptors were used as adjectives to modify the word pelo (hair). Ñuto meant kinky hair, whereas trinchudo was used to describe abundant straight hair, associated with Indians. Notably, trinchudo, and nuto have somewhat negative connotations. The preferred hair textures in Ingenio are wavy or curly hair (enrulado), or fine straight light hair (lacio). European facial features are also more highly valued. People in Ingenio occasionally insulted others by referring to them as picuda (big-lipped) or ñato (flat-nosed).

All of the descriptors discussed above are value laden and local practices ensure the preference of straighter hair, lighter skin, thinner lips, and pointier noses-European features. These preferences, however, do not necessarily mean that any of these descriptors are intermediate racial categories. These descriptors are indicative of a color, not a race, continuum. My research indicates these descriptors refer to people who fall into other generally agreed upon racial groups-blanco (white), cholo (indian), and negro (black). The labels, moreno, trigueño, and zambo point to skin color and hair texture variations within the black group. They are thus more akin to color classifications such as "light skinned" or "brown skinned" than to racial classifications such as black or white.

The extracts from these interviews indicate that color-based classifications can and do exist alongside race-based classifications. In the United States, African Americans use dark skinned, brown skinned, light skinned, red boned, high yellow, and other terms to denote differences in skin tones among people considered to be black. In Peru, people use color-coded terms such as moreno and trigneño to distinguish dark-skinned blacks from lighter-skinned blacks. The primary distinction is that, in the United States, these skin color indicators are not nearly as commonplace as in Peru. In the United States, when nonblacks refer to blacks, they almost exclusively will call them black, and almost never recognize internal differentiation among blacks. In Peru, blacks and nonblacks alike use the categories negro, moreno, zambo, and trigueño to describe people of African descent.

\section{Conclusion}

In this article, I have argued that broad claims about Latin America do not hold for the Afro-Peruvian community I studied. I have clarified the distinction between race and color labels, as they are used in this African-descended community. This clarification has allowed me to demonstrate three things: (1) There is no buffer group, as the color labels serve as descriptors, and not intermediary categories; (2) Social and cultural whitening are not possible because of the fixity of the black category; and (3) There is not a continuum of racial categories, but a continuum of color labels.

My interviewees made it clear that blackness is based on skin color and descent, not on social status or cultural attributes. In some cases, they used negro to refer to a collective group, mutually exclusive from the white group. In this sense, negro qualifies as a racial label, whereas other labels such as trigueño, moreno, and zambo are color labels that do not refer to mutually exclusive groups of people. These findings point to the importance of distinguishing between race and color in analyses of racial categorization in Latin America and beyond.

When we return to Campoverde's and Ortiz's statements at the beginning of this article, it is clear that Mirella always will be black. Ortiz's argument that racial status in Peru is fluid does not apply to blacks from Ingenio. It may continue to apply to Indians, as previous studies have indicated. And, it may apply to middle class blacks in Lima-a group that has not received much intellectual scrutiny. To make this determination, it would be necessary to conduct research in these communities. This article makes it clear that such research would require a careful distinction between race and color. 


\section{Implications for Further Research}

This article, like most articles about racial classification in Latin America, is based on a case study. I have critiqued other authors for generalizing from their case study to the rest of Latin America, so I will not commit the same error here. Instead, I will argue that the findings presented herein raise important questions for future researchers of race and color in Latin America.

The absence of a mulatto category in the community I studied points to the importance of conducting qualitative research with African-descended populations in countries with relatively small black populations to consider the persistence of the mulatto category in the postslavery era. During the era of slavery in Peru, there were legal distinctions between free blacks and slaves. There is not enough historical research on different social statuses of people of African descent in Peru to determine whether or not there was a mulatto category that enjoyed special benefits during this time. Rachel O'Toole's (2006) recent work on castas in Peru suggests that the system of identification in colonial Peru was complex and belies such simple characterizations. In Ingenio, it is clear that there is no longer such a buffer category. One reason for which there may no longer be a mulatto category is that the demographics of Peru make it such that a mulatto category is not necessary to prevent black solidarity. Blacks make up less than 10 percent of the population and do not present a collective threat to the social order. This possibility points to the need for further research on the mulatto escape hatch and social whitening in countries where blacks do not make up the majority-countries such as Mexico, Bolivia, Ecuador, and Colombia.

This article also makes it clear that the absence of a mulatto category does not mean that colorism is not an issue-preference for lighter skin is widespread in Peru. Although there is no mulatto category or group, it remains the case that Peruvians value more highly lighter skin and straighter hair. This makes Peru similar to the United States and other Latin American countries. Another area in need of further exploration is the different ways that colorism works in the United States and in Latin America. Comparative analyses of racial hierarchies would do well to incorporate comparisons of color classifications and hierarchies in their analyses.

\section{References}

Aldana, Susana. 1989. Empresas Coloniales: Las Tinas de Jabon en Piura. Piura, Peru: CIPCA.

Bonilla-Silva. Eduardo. 2004. "From Bi-Racial to Tri-Racial: Towards a New System of Racial Stratification in the USA." Ethnic and Racial Studies 27(6):931-50.

Bourricaud, François. 1975. "Indian, Mestizo, and Cholo as Symbols in the Peruvian System of Stratification." Pp. 350-90 in Ethnicity: Theory and Experience, edited by Nathan Glazer and Daniel P. Moynihan. Translated by Barbara Bray. Cambridge, MA: Harvard University Press.

Bowser, Frederick P. 1974. The African Slave in Colonial Peru, 1524-1650. Palo Alto, CA: Stanford University Press.

Brubaker, Rogers and Frederick Cooper. 2000. "Beyond Identity." Theory and Society 29(1):1-47.

Cuche, Denys. 1981. Pérou Nègre: Les Descendants d'Esclaves Africains au Pérou-Des Grands Domaines Esclavagistes aux Plantations Modernes. Paris, France: Éditions L'Harmattan.

Daniel, Reginald. 2006. Race and Multiraciality in Brazil and the United States: Converging Paths? University Park: Pennsylvania State University Press.

de la Cadena, Marisol. 2000. Indigenous Mestizos: The Politics of Race and Culture in Cuzco, 1919-1999. Durham, NC: Duke University Press.

Degler, Carl. 1986. Neither Black nor White: Slavery and Race Relations in Brazil and the United States. Madison: University of Wisconsin Press.

Duany, Jorge. 1998. “Reconstructing Racial Identity." Latin American Perspectives 25:147-73.

Dyer, Richard. 1997. White. London, UK and New York: Routledge. 
Forman, Tyrone, Carla Goar, and Amanda Lewis. 2004. “Neither Black Nor White? An Empirical Test of the Latin Americanization Thesis." Race $\theta$ Society $5(1): 65-84$.

Frankenberg, Ruth. 1997. "Introduction: Local Whitenesses, Localizing Whiteness." Pp. 1-34 in Displacing Whiteness: Essays in Social and Cultural Criticism, edited by Ruth Frankenberg. Durham, NC : Duke University Press.

Gallagher, Charles. 2000. "White Like Me?" Pp. 67-99 in Racing Research, Researching Race: Methodological Dilemmas in Critical Race Studies, edited by France Winddance Twine and Jonathan W. Warren. New York: New York University Press.

García, Maria Elena. 2005. Making Indigenous Citizens: Identities, Education, and Multicultural Development in Peru. Palo Alto, CA: Stanford University Press.

Golash-Boza, Tanya and William Darity. 2008. "Latino Racial Choices: The Effects of Skin Colour and Discrimination on Latinos' and Latinas' Racial Self-Identifications." Ethnic and Racial Studies $31(5): 899-934$.

Goldstein, Donna. 2003. Laughter Out of Place. Berkeley: University of California Press.

Graham, Richard. 1990. The Idea of Race in Latin America, 1870-1940. Austin: University of Texas Press.

Hinson, Glenn. 2000. Fire in My Bones: Transcendence and the Holy Spirit in African American Gospel. Contemporary Ethnography Series. Philadelphia: University of Pennsylvania Press.

Hocquenghem, Anne Marie. 2004. "Una Edad del Bronce en los Andes Centrales: Contribución a la Elaboración de una Historia Ambiental." Bulletin d' Institute. Frances d' Études Andines 33(2):271-329.

hooks, bell. 1989. Talking Back: Thinking Feminist, Thinking Black. Boston, MA: South End Press.

Hünefeldt, Christine. 1994. Paying the Price of Freedom. Family and Labor among Lima's Slaves, 1800-1854. Berkeley: University of California Press.

Jenkins, R. 1994. "Rethinking Ethnicity: Identity, Categorization, and Power." Ethnic and Racial Studies 17:197-223.

Jenkins, Richard. 2000. "Categorization: Identity, Social Processes, and Epistemology." Current Sociology 48(3):7-75.

Landale, Nancy S. and R. S. Oropesa. 2002. "White, Black, or Puerto Rican? Racial Self-Identification among Mainland and Island Puerto Ricans." Social Forces 81 (1):231-54.

Lassiter, Eric. 2005. The Chicago Guide to Collaborative Ethnography. Chicago: University of Chicago Press.

López Albújar, Enrique. 1928. Matalaché. Piura, Peru: El Tiempo.

McPherson, Lionel and Tommie Shelby. 2004. "Blackness and Blood: Interpreting African African-American Identity." Philosophy and Public Affairs 32(2):171-92.

Miles, Robert and Rodolfo Torres. 1999. “Does 'Race' Matter?” Pp. 19-38 in Race, Identity, and Citizenship: A Reader, edited by Rodolfo D. Torres, Luis F. Mirón, and Jonathan Xavier Inda. Malden, MA: Blackwell Publishers.

Nagel, Joane. 1994. “Constructing Ethnicity: Creating and Recreating Ethnic Identity and Culture." Social Problems 41 (1):152-76.

Oboler, Suzanne. 2005. "The Foreignness of Racism: Pride and Prejudice among Peru's Limeños in the 1990s." Pp. 76-100 in Neither Enemies nor Friends, edited by Suzanne Oboler and Anani Dzidzienyo. New York: Palgrave MacMillan.

Ortiz, Alejandro. 2001. "El Término Raza como Homonimia." In La Pareja y el Mito. Estudios sobre las Concepciones de la Persona y de la Pareja en los Andes Lima, edited by Alejandro Ortiz. Lima, Peru: Fondo Editorial de la Pontificia Universidad Católica del Perú.

O'Toole, Rachel. 2006. "'In a War against the Spanish': Andean Protection and African Resistance on the Northern Peruvian Coast." The Americas 63(1):19-52.

Rodríguez, Clara E. 2000. Changing Race: Latinos, the Census, and the History of Ethnicity in the United States. New York: New York University Press.

Safa, Helen. 1998. "Introduction." Latin American Perspectives 25(3):3-20.

Sansone, Livio. 2003. Blackness without Ethnicity: Constructing Race in Brazil. New York: Palgrave MacMillan.

Schlüpmann, Jakob. 1991. "Structure Agraire et Formation d'un Ordre Social au Nord du Pérou: Piura à l'Epoque Coloniale." Bulletin d' Institute. Frances d' Études Andines 20(2):461-88.

Schwartzman, Luisa. 2007. “Does Money Whiten?" American Sociological Review 72(2):940-63.

Scott, James. 1987. Weapons of the Weak: Everyday Forms of Peasant Resistance. New Haven, CT: Yale University Press.

Sheriff, Robin. 2001. Dreaming Equality: Color, Race, and Racism in Urban Brazil. Piscataway, NJ: Rutgers University Press. 
—. 2003. "Embracing Race: Deconstructing Mestiçagem in Rio de Janeiro." Journal of Latin American Anthropology 8(1):86-115.

Skidmore, Thomas. 1993. "Bi-Racial USA versus Multi-Racial Brazil: Is the Contrast Still Valid?" Journal of Latin American Studies 25(2):373-86.

Smedley, Audrey. 2007. The Idea of Race in North America. Boulder, CO: Westview Press.

Sue, Christina. 2009. "An Assessment of the Latin Americanization Thesis." Ethnic and Racial Studies 32(6):1058-70.

Sue, Christina and Tanya Golash-Boza. 2009. "Blackness in Mestizo America: The Cases of Mexico and Peru." Latino Research Review 7(1/2):30-58.

Telles, Edward. 2004. Race in Another America: The Significance of Skin Color in Brazil. Princeton, NJ: Princeton University Press.

Van den Berghe, Pierre. 1974. "The Use of Ethnic Terms in the Peruvian Social Science Literature. Pp. 12-22 in Class and Ethnicity in Peru, edited by Pierre van den Berghe. Leiden, The Netherlands: E. J. Brill.

Varallanos, José. 1962. El Cholo y El Perú. Buenos Aires, Argentina: Imprenta López.

Wade, Peter. 1993. Blackness and Race Mixture: The Dynamics of Racial Identity in Colombia. Baltimore, MD: Johns Hopkins University Press.

1997. Race and Ethnicity in Latin America. Chicago: Pluto Press.

Weismantel, Mary. 2001. Cholas and Pishtacos: Stories of Race and Sex in the Andes. Chicago: University of Chicago Press.

Wright, Winthrop. 1990. Café con Leche: Race, Class, and National Image in Venezuela. Austin: University of Texas Press. 